\title{
The effect of transfer funds to regions and village funds on human development index in districts of west java province in 2015-2018
}

\author{
Muhammad Afrizal Yusuf, ${ }^{1}$ Arif Afendi ${ }^{2}$ \\ 1,2Universitas Islam Negeri Walisongo Semarang, Indonesia \\ email:m.21afrizal@gmail.com
}

\begin{abstract}
Purpose - This research aims to analyze the influence of the Revenue Sharing Fund, General Allocation Fund, Special Allocation Fund, and Village Fund on the level of Human Development Index in 18 Districts in West Java Province in 2015-2018.

Method - The data used in this study were secondary. The Revenue Sharing Fund, General Allocation Fund, Special Allocation Fund, and Village Fund are obtained from the Central Government Financial Report from the Ministry of Finance. Meanwhile, the human development index data were obtained from the Central Bureau of Statistics (BPS). The data were analyzed using multiple linear regressions.

Result - The results showed that the revenue sharing fund had a positive and significant effect on the Human Development Index, the general allocation fund had a negative and significant effect on the human development index, the special allocation fund had a positive but insignificant effect on the human development index, while the village fund had a negative and insignificant effect on the human development index.

Implication - This study provides information that in the implementation of effective transfers of funds in the process of receiving or transferring funds from provinces to regions, certainty and clarity regarding expenditure burdens or authority is needed which is a prerequisite for the successful implementation of fiscal decentralization policies through fund transfers so that an increase in the human development index can be achieved.

Originality - By using secondary data from a sample of districts and cities in West Java, this study illustrates how the influence of Transfer Funds to Regions and Village Funds in increasing the Human Development Index.
\end{abstract}

Keywords: revenue sharing fund; general and special allocation fund; 


\section{Introduction}

Government reform accompanied by openness is already a demand in Indonesia. It has led to stronger demand for transparency and accountability. JIAFR | 154 Both aspects are important in government management, including in the field of financial management of countries and regions. That prompted the transition from a deconcentration system to a decentralized system called autonomy. Autonomy is the delegation of central government affairs to local governments that are operational in the framework of the system of government bureaucracy (Siregar, 2017).

According to Badrudin (2017), regions in Indonesia which include provinces, districts/cities, sub-districts, and villages need a regulating system so that regional inequality is not widening which is the regional autonomy system. In other words, the local government has the authority to make local policies to provide services, increase participation, give initiatives, and community empowerment aimed at improving the welfare of the community.

According to Sukanto (2018), the consequence of the implementation of regional autonomy is that each region is given the freedom to organize and dig its regional revenue source. However, it is very diverse because each region has a different source of natural wealth. Some areas have abundant natural resources and high-income taxes. Yuardani, Zulyanto \& Tejo (2019) On the other hand, some areas otherwise have limited natural resources so that the income from taxes becomes low. The implication is that the central government must continue to assist in the region to carry out distribution functions to create equalization of development outcomes.

According to the Directorate General of Balance (2016), the increased budget for transfers to regions and village funds is aimed at realizing the government's aspiration to build Indonesia from the periphery by strengthening regional and village regions within the framework of the Republic of Indonesia. In the Islamic view, the main focus and core of development is human development itself, including social and cultural aspects. This is by the Quran Hud; 61. 
The effect of transfer funds to regions and village funds on ...

Table 1. Transfer Fund Revenue Comparison

(in billion rupiah)

\begin{tabular}{|c|c|c|c|c|}
\hline \multirow{2}{*}{ Provinces } & \multicolumn{2}{|c|}{2015} & \multicolumn{2}{|c|}{2016} \\
\hline & Total & Average & Total & Average \\
\hline West Java & Rp 55,062.84 & Rp 2,039.37 & Rp 59,675.74 & Rp 2,210.21 \\
\hline Central Java & $\operatorname{Rp} 53,027.18$ & Rp 1,515.06 & Rp 5,9007.50 & Rp 1,685.93 \\
\hline East Java & Rp 61,040.99 & Rp 1,606.34 & Rp 66,966.34 & Rp 1,762.27 \\
\hline \multirow{2}{*}{ Provinces } & \multicolumn{2}{|c|}{2017} & \multicolumn{2}{|c|}{2018} \\
\hline & Total & Average & Total & Average \\
\hline West Java & Rp 64,734.65 & Rp 2,397.58 & Rp 65,036.38 & Rp 2,408.75 \\
\hline Central Java & Rp 64,378.16 & Rp 1,839.36 & Rp $64,1800.58$ & Rp 1,833.72 \\
\hline East Java & $\operatorname{Rp} 72,012.21$ & Rp 1,895.06 & $\operatorname{Rp} 75,828.74$ & Rp 1,995.49 \\
\hline
\end{tabular}

JIAFR | 155

Source: LKPP 2015-2018

This verse contains an explanation of God's absolute command for men to create prosperity on earth. One of the methods used to measure how regional autonomy through the mechanism of transfer to regions and village funds is managed well for the welfare of the community is by looking at the Human Development Index.

Table 2 explains that Transfer Funds to Regions from all districts and cities in West Java Province in 2015-2018 have the highest increase and is highest of Central Java and East Java Provinces. However, it is not in line with the average value of its Human Development Index (HDI). It indicates that the high transfer of funds provided by the central government to the regions is not able to improve the quality of human resources in the areas. The funds are likely used for the development of other more important infrastructures.

Table 2. Comparison of Average Value of District/City HDI

\begin{tabular}{lllll}
\hline \multicolumn{1}{c}{ Provinces } & 2015 & 2016 & 2017 & 2018 \\
\hline West java & 69,18 & 69,68 & 70,14 & 71,20 \\
Central java & 70,08 & 70,61 & 71,19 & 71,79 \\
East java & 68,93 & 69,81 & 70,35 & 71,24 \\
\hline
\end{tabular}

Source: BPS HDI 2015-2018

Journal of Islamic Accounting and Finance Research - Vol. 2 No. 2 (2020) 
The result of Budi's research (2017) on The Effect of Regional Revenue, Balancing Fund and Regional Expenditure to the Human Development Index on Regency/City Governments in Central Java in 2012-2014 showed that Real Regional Income (RRI), Special Allocation Fund, and Revenue Sharing Fund do not affect Human Development Index. Regional Expenditure has a positive and significant effect on Human Development Index; while General Allocation Fund has a negative and significant effect on the Human Development Index.

Siswadi's research (2015) found that RRI has a positive and significant effect on Human Development Index; while General Allocation Fund and Gross Regional Domestic Product has a negative and significant effect on Human Development Index. Based on the background, the purpose of this research is to examine the effect of the Transfer Fund to Regions and Village Fund on the Human Development Index.

\section{Literature Review}

\section{Stewardship Theory}

Stewardship theory describes situations where management is not motivated by individual goals but is aimed at their primary outcome goals for the benefit of the organization. The theory assumes a strong relationship between satisfaction and organizational success. The organization's success illustrates the maximization of the utility of principals and management groups. Maximizing the utility of this group will ultimately maximize the interests of individuals in the organizational group.

\section{Effectiveness of Budget Management}

Mardiasmo (2009) defines that effectiveness is essentially related to achieving policy goals or targets. Effectiveness is a comparison between the target and the result that has been achieved. The closer it is between the target and the result achieved the more effective a planning is. A budget is a statement of performance estimates to be achieved over a certain period stated in the financial measure. Public sector budgets are an instrument of 
accountability for the management of public funds and the implementation of programs financed with public money. The budget has several main functions including as a planning tool and as a control tool. As a planning tool, the budget indicates the target that must be achieved by the government; while as a means of control, the budget indicates the allocation of legislatively approved sources of public funds to spend.

\section{Transfers to Regions and Village Funds}

Transfers to Regions and Village Fund are part of state expenditure to fund the implementation of fiscal decentralization in the form of Balancing Fund, Special Autonomy Fund, Yogyakarta Special Regency Privileges Fund, Regional Incentive Fund, and Village Fund (Siregar, 2017). According to UU No. 33 the Year 2004, Balancing Funds are funds sourced from the receipt of the State Budget which are allocated to the regions to finance their needs in the context of implementing regional autonomy consisting of Revenue Sharing Fund, General Allocation Fund, and Special Allocation Fund.

\section{Revenue Sharing Fund}

According to Astuti (2020), Revenue Sharing Fund is a fund sourced from the State Budget Revenues that are allocated to regions with a certain percentage rate, to fund regional needs in the context of implementing decentralization. Revenue Sharing Fund includes tax results and natural resource results.

\section{General Allocation Fund}

According to UU No. 33, 2004 on Financial Balance between the Central Government and Regional Governments states that the General Allocation Fund is a fund originating from the State Budget which is allocated with the aim of equitable distribution of financial capacity between regions to finance their expenditure needs in the context of implementing decentralization. The amount of the General Allocation Fund nationally is at least $26 \%$ of the Net Domestic Revenue. Calculation of the allocation of the General Allocation 
Muhammad Afrizal Yusuf, Arif Afendi

Fund is carried out using a formula consisting of basic allocation and fiscal gap.

\section{Special Allocation Fund}

JIAFR | 158

According to UU No. 33 Article 1, 2004 on Financial Balance between Central Finances and Regional Finances explains that the Special Allocation Fund is a fund sourced from the State Budget Revenues allocated to certain regions to fund special activities which are included in the regional affairs and accordance with national priorities consisting of special physical and nonphysical allocation funds.

\section{Village Fund}

The fund allocated in the State Budget is intended for villages that are transferred through the district/city's Regional Revenue and Expenditure Budget and are used to finance governance, development realization, community development, and community empowerment. Based on the mandate of According to UU No. 6 the Year 2014 on Villages, the budget for villages is allocated by streamlining the village-based program equally and equitably.

\section{Human Development Index (HDI)}

The HDI was created to emphasize that people and their capabilities should be the ultimate criteria for assessing the development of a country, not economic growth alone. The HDI can also be used to question national policy choices, asking how two countries with the same level of Gross National Income (GNI) per capita can end up with different human development outcomes. These contrasts can stimulate debate about government policy priorities. The Human Development Index (HDI) is a summary measure of average achievement in key dimensions of human development: a long and healthy life, being knowledgeable, and have a decent standard of living. The HDI is the geometric mean of normalized indices for each of the three dimensions. 


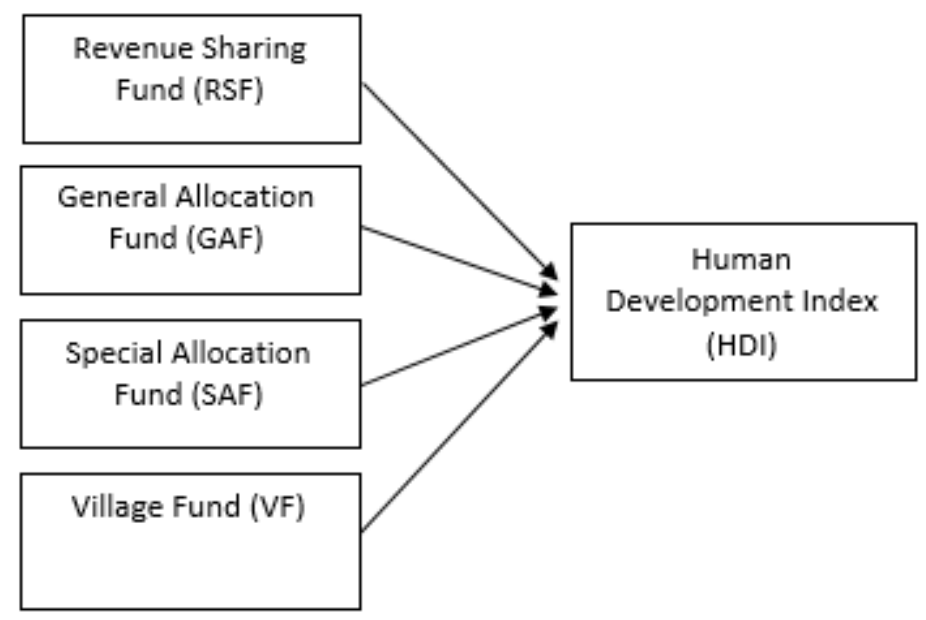

JIAFR | 159

Figure 1. Research Framework

The health dimension is assessed by life expectancy at birth, the education dimension is measured by means of years of schooling for adults aged 25 years and more and expected years of schooling for children of school entering age. The standard of living dimension is measured by GNI per capita. The HDI uses the logarithm of income, to reflect the diminishing importance of income with increasing GNI. The scores for the three HDI dimension indices are then aggregated into a composite index using geometric mean.

The HDI simplifies and captures only part of what human development entails. It does not reflect on inequalities, poverty, human security, empowerment, etc. The Human Development Report Office (HDRO) offers the other composite indices as a broader proxy on some of the key issues of human development, inequality, gender disparity, and poverty.

\section{Hypothesis Development}

Widarwanto, Erlina, and Yahya (2014), Siswadi (2015), Hayati, and Achasa (2016) state that the Revenue Sharing Fund had a positive effect on the Human Development Index. The Revenue Sharing Fund is a fund sourced 
from the State Budget Revenues allocated to regions with a certain percentage figure, to fund regional needs to implement decentralization. The Revenue Sharing Fund consists of the Tax Revenue Sharing Fund and the Natural Resources Revenue Sharing Fund.

\section{$H_{1}$ : Revenue Sharing Fund has a positive effect on the Human Development Index}

Siswadi (2015) and Budi (2017) state that the General Allocation Fund negatively affects the Human Development Index. The General Allocation Fund is a type of Balancing Fund that has an important role in improving the equalization of financial capabilities between regions to fund regional needs to decentralize to carry out the functions of public basic services.

$H_{2}$ : General Allocation Fund has a positive effect on Human Development Index

Widarwanto, Erlina, and Yahya (2014), Siswadi (2015), and Hasan and Agung (2018) state that the Special Allocation Fund had a positive effect on the Human Development Index. Special Allocation Fund is allocated to regions to fund certain activities that become regional affairs, both physical and non-physical activities.

\section{$H_{3}$ : Special allocation fund has a positive effect on the Human Development Index}

Rusyidi (2012) and Afrilianto (2017) state that the Village Fund had a positive effect on economic growth and social welfare which is quite relevant because the Human Development Index includes a measure of the social welfare. Village Fund is a fund sourced from the State Budget allocated to each village and used to fund the village authority affairs which includes government, development, community empowerment, and community affairs.

$H_{4}$ : Village Fund has a positive effect on the Human Development Index 
The effect of transfer funds to regions and village funds on ...

\section{Research Methods}

This research is field research with a quantitative approach. The sample was taken form 18 regencies and cities government in West Java province in 2015-2018. The data used secondary data obtained from the Ministry of Finance (www.kemenkeu.go.id). While the data of human capital index were JIAFR | 161 taken from the Central Bureau of Statistics (www.ipm.bps.go.id). This research model uses multiple linear regression.

\section{Results and Discussion}

Multiple linear regression analysis is an analysis model that serves to determine the effect of independent variables on dependent variables.

\section{The Effect of Revenue Sharing Fund on Human Development Index}

Table 3 shows that the Revenue Sharing Fund has a positive and significant effect on the Human Development Index. It is evidenced by a regression coefficient value of 1,562 with a significance value of 0.000 smaller than 0.05 . It means the $\mathrm{H} 1$ hypothesis is accepted. This is by the Regulations of Financial Ministry Number 230/PMK.07/2017 and Number 222/PMK.07/2017 that there are several components of the Revenue Sharing Fund whose use is determined by the country based on the relevant regulations (earmarking). These components include the Forestry Natural Resources Share Fund derived from the reforestation fund used in part for research and development, education and training, counseling, and empowerment of local communities in forest rehabilitation activities. On the other hand, the receipt of tax revenue share from tobacco excise is at least $50 \%$ used for health activities. Thus, the increase in the Share Fund can lead to an increase in the Human Development Index.

This research is by the research of Hayati and Achasa (2016), Widarwanto, Erlina, and Yahya (2014), and Siswadi (2015) which state that the Revenue Sharing Fund has a positive and significant effect on the Human Development Index. The Revenue Sharing Fund can influence the Human Development Index through Capital Expenditure, increasing the Revenue 
Sharing Fund will also increase capital expenditures. This increase in capital expenditure will also have an impact on improving the social welfare implemented through the provision of education, health, and economic services reflected by the increasing Human Development Index.

\section{The Effect of General Allocation Fund on Human Development Index}

As shown in Table 3, the General Allocation Fund has a negative and significant effect on the Human Development Index. It is evidenced by a regression coefficient value of $-2,187$ with a significance value of 0.016 smaller to 0.05 . It means that the $\mathrm{H} 2$ hypothesis is accepted.

The results of this study support Budi's research (2017), Siswadi (2015) and Awwaliyah, Agriyanto \& Farida (2019) which states that the General Allocation Fund negatively and significantly affects the Human Development Index. High General Allocation Fund allocation with a basic allocation component is still the main component that dominates the overall General Allocation Fund received by the district. The basic allocation is the budget allocation used for employee spending so that most of it is used for employee spending is not used for capital expenditures. Therefore, the increase in the General Allocation Fund leads to a decrease in HDI.

Table 3. Multiple Linear Regression Test

\begin{tabular}{lllllll}
\multicolumn{7}{c}{ Coefficients } \\
\hline \multicolumn{7}{c}{$\begin{array}{l}\text { Unstandardized } \\
\text { Coefficients }\end{array}$} \\
& B & Std. Error & $\begin{array}{l}\text { Standardized } \\
\text { Coefficients } \\
\text { Beta }\end{array}$ & T & Sig. \\
\hline 1 & (Constant) & 67,495 &, 942 & & 71,675 &, 000 \\
& DBH & $1,562 \mathrm{E}-11$ &, 000 &, 614 & 5,716 &, 000 \\
& DAU & $-2,187 \mathrm{E}-12$ &, 000 &,- 317 & $-2,478$ &, 016 \\
& DAK & $3,670 \mathrm{E}-12$ &, 000 &, 258 & 1,138 &, 259 \\
& DD & $-5,329 \mathrm{E}-12$ &, 000 &,- 207 &,- 943 &, 349 \\
\hline
\end{tabular}

a. Dependent Variable: HDI

Source: Processed data (2019) 
The effect of transfer funds to regions and village funds on ...

\section{The Effect of the Special Allocation Fund on Human Development Index}

Table 3 also shows that the Special Allocation Fund has a positive but insignificant effect on the Human Development Index. It is evidenced by a regression coefficient value of 3,670 with a significance value of 0.259 greater than 0.05. It means that the $\mathrm{H} 3$ hypothesis is accepted.

JIAFR | 163

The results of this study are in line with the research of Widarwanto et al. (2014) and Siswadi (2015) that the Special Allocation Fund has a positive but insignificant effect on the Human Appropriations Index because the allocation of Special Allocation Fund has not focused on expenditures that support the improvement of people's access to education, health, and economic elements. The relatively low amount of the Special Allocation Fund is divided into many areas including education, health and family planning program, drinking water, sanitation, housing and settlements, markets, small and medium-sized industries, agriculture, marine and fisheries, tourism, and roads. So, the Special Allocation Fund has a positive but insignificant effect on the Human Development Index.

\section{The Effect of Village Fund on Human Development Index}

Table 3 shows that the Village Fund has a negative but insignificant effect on the Human Development Index. It is evidenced by a regression coefficient value of $-5,329$ with a significance value of 0.349 greater than 0.05 . It means the H4 hypothesis is rejected.

The result is by the opinion of the state budget policy center's review team on the benefits of the Village Fund. Eka (2020), the utilization of Village Fund is more widely used for the priority of basic infrastructure developments such as roads, bridges, drainage, irrigation, and pond while the utilization of Village Fund for community empowerment has not been optimal, so the Village Fund has a negative but insignificant effect on the Human Development Index. 
Muhammad Afrizal Yusuf, Arif Afendi

Table 4. F-test

JIAFR | 164

\begin{tabular}{lllllll}
\hline Model & & Sum of Squares & Df & Mean Square & $\mathrm{F}$ & Sig. \\
\hline 1 & Regression & 156,812 & 4 & 39,203 & 9,018 &, $000^{\mathrm{b}}$ \\
& Residual & 291,248 & 67 & 4,347 & & \\
& Total & 448,059 & 71 & & & \\
\hline
\end{tabular}

a. Dependent Variable: HDI

Source: Processed data (2019)

Table 5. Determination coefficient test $\left(\mathbf{R}^{2}\right)$

\begin{tabular}{|c|c|c|c|c|}
\hline Model & $\mathrm{R}$ & R Square & $\begin{array}{l}\text { Adjusted R } \\
\text { Square }\end{array}$ & $\begin{array}{l}\text { Std. The error of the } \\
\text { Estimate }\end{array}$ \\
\hline 1 &, $592^{\mathrm{a}}$ & ,350 & ,311 & 2,08494 \\
\hline
\end{tabular}

\section{Full Model Test (F-test)}

The results of the regression test in Table 4 show a probability value of F of 0.000 smaller than 0.05 . So, it can be concluded that the regression model is worth using to explain the research variables.

\section{Determination Coefficient Test $\left(\mathbf{R}^{2}\right)$}

Table 5 shows that the R-Square value of 0.350 means that the Human Development Index can be influenced by variables such as Revenue Share Fund, General Allocation Fund, Special Allocation Fund, and Village Fund; while $65 \%$ is explained by other variables outside the study.

\section{Conclusion}

Based on the results of the above research, it can be concluded that the Revenue Sharing Fund has a positive and significant effect on the Human Development Index meaning that the increase in the Revenue Sharing Fund can increase the Human Development Index. The General Allocation Fund has a negative and significant effect on the Human Development Index, which 
means that the increase in the General Allocation Fund could lead to a decrease in the Human Development Index. Special Allocation Fund has a positive but insignificant effect on the Human Development Index meaning that the increase in the Special Allocation Fund can increase the Human Development Index. While Village Fund has a negative but insignificant effect on the Human Development Index which means that any increase in Village Fund could lead to a decrease in the Human Development Index.

Based on the research results, it can be suggested that the local governments have to facilitate the optimization of village assistance functions to increase the capacity of the village fund management apparatus. Local governments have to hold cooperation between districts, sub-districts, and adjacent villages to achieve the targeted programs in disadvantaged areas, especially in border areas. Cooperation can be done by utilizing the Village Fund through village-owned enterprises for the development of economic potential and community empowerment. It is recommended that further researches use a longer observation period to get better results and increase some variables and emphasize education, health, economics, and others.

\section{References}

Afrilianto. (2017). Analisis Dampak Alokasi Dana Desa Terhadap Pertumbuhan Ekonomi di Kabupaten Bogor. Skripsi, Fakultas Ekonomika dan Manajemen IPB Bogor.

Astuti, R. P. (2020). The Influence of Good Corporate Governance on Sukuk Rating. Journal of Islamic Economics and Social Science (JIESS). 1(1), 4348.

Awwaliyah, N. F., Agriyanto, R., \& Farida, D. N. (2019). The effect of regional original income and balance funding on regional government financial performance. Journal of Islamic Accounting and Finance Research. 1(1), 25-46. https://doi.org/10.21580/jiafr.2019.1.1.3745.

Badan Pusat Statistik. Indeks Pembangunan Manusia Kabupaten/Kota Provinsi Jawa Barat Tahun 2015-2018. http://www.ipm.bps.go.id. Downloaded on 13 May 2019.

Badrudin, R. (2017). Ekonomika Otonomi Daerah. Yogyakarta: UPP STIM YKPN. 
Muhammad Afrizal Yusuf, Arif Afendi

Budi. (2017). Pengaruh Pendapatan Asli Daerah, Dana Perimbangan dan Belanja Daerah terhadap Indeks Pembangunan Manusia pada Pemerintah Kabupaten/Kota di Jawa Tengah Tahun 2012-2014. Skripsi, Fakultas Ekonomi dan Bisnis Islam Institut Agama Islam Negeri Surakarta.

Ditjen Perimbangan. Dana Transfer ke Daerah untuk Nawacita. http://www.kemenkeu.go.id/publikasi/berita/anggaran-transfer-ke-daerahdan-dana-desa-untuk-mewujudkan-nawacita/. Accessed on 12 March 2019.

Eka, S. (2020). Pengaruh Nilai Tukar dan Produk Domestik Bruto Dunia terhadap Volume Ekspor Indonesia.Permana: Jurnal Perpajakan, Manajemen, Dan Akuntansi.12(2), 87-97. https://doi.org/10.24905/permana.v12i2.97.

Hasan \& Agung. (2018). Pengaruh Pendapatan Asli Daerah, Dana Alokasi Umum Dan Dana Alokasi Khusus Terhadap Indeks Pembangunan Manusia Dengan Alokasi Belanja Modal Sebagai Variabel Intervening (Studi Pada Kabupaten/Kota Propinsi Riau Periode 2011-2015). Jurnal Fakultas Ekonomi dan Bisnis Universitas Riau.

Hayati \& Achasa. (2016). Dampak Desentralisasi Fiskal terhadap IPM Di Indonesia. Jurnal Ekonomi Fakultas Ekonomi, Universtas Tidar, Magelang.

Kementrian Keuangan. Laporan Keuangan Pemerintah Pusat 2015-2018. http://www.kemenkeu.go.id. Downloaded tanggal 30 May 2019.

Kementerian Keuangan. Nota Keuangan dan APBN 2015-2018. http://www.kemenkeu.go.id. Downloaded on 13 May 2019.

Peraturan Menteri Keuangan Republik Nomor 230/PMK.07/2017 tentang Penggunaan, Pemantauan dan Evaluasi Dana Bagi Hasil Sumber Daya Alam Kehutanan Dana Reboisasi.

Peraturan Menteri Keuangan Republik Nomor 230/PMK.07/2017 tentang Penggunaan, Pemantauan dan Evaluasi Dana Bagi Hasil Cukai Hasil Tembakau.

Mardiasmo. (2009). Akuntansi Sektor Publik. Yogyakarta: Andi Yogyakarta.

Siregar, B. (2017). Akuntansi Sektor Publik. Yogyakarta: UPP STIM YKPN. 
Siswadi. (2015). Pengaruh Pertumbuhan Ekonomi, PAD dan Perimbangan terhadap Indeks Pembangunan Manusia melalui Belanja Modal. Jurnal Manajemen Universitas Mataram.

Sukanto. (2018). Dampak Dana Transfer dan Peran Kelembagaan terhadap Kinerja Pembangunan di Propinsi Banten. Disertasi Doktor Studi Perencanaan Pembangunan, Institut Pertanian Bogor.

Undang-Undang Republik Indonesia Nomor 33 Tahun 2004 Tentang Perimbangan Keuangan Antara Pemerintah Pusat Dan Pemerintahan Daerah.

Undang-undang Nomor 33 pasal 1 Tahun 2004 tentang Perimbangan Keuangan antara Keuangan antara pemerintah Pusat dan Keuangan Daerah.

Undang - Undang Nomor 6 Tahun 2014 tentang Pemerintahan Desa.

Yuardani, A. M., Zulyanto, D., \& Tejo, A. E. (2019). Evaluasi terhadap Pembangunan PLB Terkait dengan Perspektif Sosial Masyarakat di Kecamatan Nanga Badau. Eksos, 15(1), 1-18.

Widarwanto, E., \& Yahya. (2014). Pengaruh DAU, DAK, PAD, DBH, BKP terhadap IPM dengan BPD sebagai moderating variabel. Jurnal Telaah \& Riset Akuntansi, 7(2). 
JIAFR | 168 